\title{
TOKSISITAS LIMBAH CAIR INDUSTRI BATIK TERHADAP MORFOLOGI SISIK IKAN NILA GIFT (Oreochomis nilotocus)
}

\author{
Riska Andriani ${ }^{1)}$, Hartini ${ }^{2)}$ \\ ${ }^{1)}$ Program Studi Biologi Fakultas MIPA Universitas PGRI Ronggolawe Tuban, \\ ${ }^{2}$ MA Salafiyah Asy_Syafi'iyah Jatirogo \\ E-mail: andriani.riska88@yahoo.co.id
}

\begin{abstract}
The development of batik industry has increased along with the increasing of society requirement of textile material. Colored liquid in the batik industry has the potential to pollute the environment, so it is necessary research that aims to determine the toxicity of batik industrial waste to morphology of Nila Gift fish (Oreochromis niloticus). The test results of COD content contained in the batik industrial liquid waste is $4951,75 \mathrm{mg} / \mathrm{L}$, analysis of TSS content of batik wastewater showed $448 \mathrm{mg} / \mathrm{L}$, while chromium $(\mathrm{Cr})$ content was $7.0 \mathrm{mg} / \mathrm{L}$, and $\mathrm{pH}$ was 6,9 . The value of LC-50 96 hours of batik industrial liquid waste is $0.73 \%$, so that the treatment concentration is $0 \%$; $0.37 \%$; $0.46 \%$; $0.55 \% ; 0.64 \%$; and $0.73 \%$. The results showed that the scales exposed directly to batik liquid waste occurred attachment of different substances in each treatment. Treatment with the highest concentration of $0.73 \%$ shows the result of attachment of foreign substances that meet the cross section of Nila Gift fish seed scales.
\end{abstract}

Keywords: liquid waste, batik, scales, tilapia gift

\section{PENDAHULUAN}

Meningkatnya minat masyarakat akan batik gedhog khas Tuban menyebabkan industri batik di Kabupaten Tuban berkembang pesat.Dampak yang ditimbulkan dari aktivitas industri batik terutama limbah cair yang dihasilkan dari proses produksi batik dapat mencemari lingkungan. Industri batik menggunakan bahan-bahan kimia dan air yang tergolong tinggi dalam proses produksi batik. Bahan kimia yang digunakan pada proses pewarnaan atau pencelupan dapat meningkatkan jumlah limbah cair di lingkungan.

Sebagian besar industri batik dalam skala rumah tangga tidak memiliki sistem IPAL (Instalasi Pengolahan Air Limbah) untuk menangani limbahnya sehingga membuang langsung limbahnya ke selokan yang akhirnya akan bermuara ke sungai. Keadaan ini dapat mengganggu estetika perairan, menghalangi penetrasi sinar matahari ke dalam badan air,menurunkan kualitas lingkungan dan merusak kehidupan yang ada di lingkungan tersebut, selain itu jika bersentuhan langsung dengan kulit manusia dapat menimbulkan rasa gatal, panas, kulit kering, dan keras (Masfufah et al., 2007). Adanya aliran limbah yang masuk ke dalam aliran sungai akan dapat mempengaruhi kondisi sungai baik secara fisik, kimiawi ataupun biologis. Hal ini dapat diketahui dengan mengukur parameter sampel limbah cair industri batik yang dibuang ke sungai tersebut.

Ketika badan air mengalami pencemaran oleh limbah industri batik, maka akan berpengaruh terhadap beberapa komponen yang ada dalam badan air tersebut. Ikan 
merupakan organisme perairan yang paling mudah terpengaruh oleh kondisi perairan yang terdampak akibat buangan limbah atau polutan baik yang berasal dari industri maupun rumah tangga. Pada ikan yang hidup dalam habitat terbatas (seperti sungai, danau, dan teluk), ikan sulit menghindar dari pengaruh pencemaran, sehingga unsur-unsur pencemaranmasuk ke dalam tubuhnya. Ikan nila gift (Oreochromis niloticus)sebagai organisme ikan tawar yang hidup di sungai tersebut terancam keberadaannya. Tidak menutup kemungkinan bahwa kadar limbah batik di perairan dapat melebihi baku mutu yang ditentukan, sehingga menimbulkan efek negatif berupa kematian biota. Untuk mengetahui unsur pencemar penyebab terganggunya kehidupan biota dan pengaruh yang ditimbulkannya terhadap biota yang ada, dapat diketahui dari hasiluji toksisitas dengan menggunakan hewan uji (Mangkoedihardjo, 2005). Masuknya bahan pencemar berupa kandungan logam berat industri batik tersebut sangat merugikan bagi kehidupan terutama bagi biota perairan tempat pembuangan limbah cair tersebut seperti ikan nila gift.

Ikan nila gift merupakan komoditas penting perikanan budidaya air tawar di Indonesia. Ikan ini dapat hidup dan berkembang pesat walaupun pada lingkungan perairan yang kurang baik. Ikan ini dapat hidup sangat baik pada berbagai kondisi air kecuali yang beracun (Boyd, 1990). Ikan nila gift merupakan salah satu jenis hewan yang direkomendasikan oleh EPA (Environmental Protection Agency) sebagai hewan uji karena ikan tersebut memenuhi persyaratan yaitu penyebarannya cukup luas, banyak dibudidayakan, mempunyai kemampuan yang tinggi dalam mentoleransi lingkungan yang buruk dan mudah dipelihara di laboratorium (Radiopoetra, 1996).

Untuk mengetahui toksisitas limbah cair industri batik dapat dilakukan pengujian secara biologi, karena kondisi percobaan dapat diawasi dan respon makhluk hidup yang diuji dapatdigunakan sebagai monitoring berkala suatu limbah (Dhahiyat dan Djuangsih, 1997). Dalam penelitian ini digunakan benih ikan nila gift (Oreochromis niloticus) sebagai hewan uji karena ikan nila gift merupakan salah satu jenis hewan yang hidup di area sungai tempat pembuangan limbah batik.

Penyerapan logam oleh ikan akan terakumulasi pada organ tubuhnya terutama pada insang dan sisik.Sisik pada ikan berfungsi sebagai organ proteksi dari pengaruh luar (Soegianto dkk., 2005). Pengujian sisik pada benih ikan nila gift diharapkan dapat memberikan informasi mengenai besarnya pengaruh yang ditimbulkan akibat keberadaan limbah buangan industri batik terhadap kehidupan dalam badan air di sekitar lokasi pembuangan limbah (Darmono, 1991). Morfologi dapat digunakan sebagai biomarker dalam mengevaluasi kesehatan ikan atau biota lain yang terpapar kontaminan, yang dapat dilakukan baik dalam skala laboratorium maupun skala lapangan (Martinez dan Marina, 2007). Mengingat besarnya pengaruh dan akibat yang ditimbulkan oleh limbah industri batik yang ada di Kabupaten Tuban, maka perlu dilakukan suatu penelitian untuk menguji toksisitas limbah cair industri batik terhadap organisme, khususnya terhadap organisme air.Sehingga perlu dilakukan penelitian untuk mengetahui konsentrasi limbah hasil industri batik yang menyebabkan kematian pada $50 \%$ (LC50) benih ikan nila gift melalui uji hayati (bioassay). Dengan demikian dapat diketahui dampak pemaparan limbah cair industri batik terhadap morfologi sisik benih ikan nila gift (Oreochromis niloticus).

\section{METODE PENELITIAN}

Penelitian yang digunakan dalam penelitian ini adalah jenis penelitian eksperimental yaitu mengetahui nilai toksisitas akut LC-50 96 jam limbah cair industri batik dan efek sublethalnya terhadap morfologi sisik benih ikan nila gift. Alat dan bahan yang digunakan digunakan untuk mengamati 
morfologi sisik benih ikan nila gift antara lainspektrofotometer, neraca analitik, lup, pinset, mikroskop, papan seksio, tissu, kertas, benih ikan nila gift, limbah cair batik, dan akuades.

Sebelum dilakukan pengujian, hewan uji terlebih dahulu diaklimasi yang dilakukan di dalam bak air berisi air tawar yang diaerasi menggunakan aerator. Hewan uji dipuasakan terlebih dahulu sebelum dan dilanjutkan selama penelitian.Hewan uji yang digunakan dalam penelitian adalah benih ikan nila gift yang berukuran seragam yaitu 4-5 $\mathrm{cm}$. Hewan uji yang digunakan berjumlah dua ribu ekor. Pemilihan hewan uji pada tahap benih tersebut didasarkan karena pada tahap awal hidupnya hewan lebih sensitif terhadap masukan bahan toksik yang berasal dari luar perairan.

Tahap penelitian meliputi pengambilan sampel limbah cair industri batik, analisis fisika dan kimia limbah industri batik, pengukuran faktor fisika kimia larutan uji, uji LC-50, serta uji toksisitas benih ikan nila gift.Penghitungan nilai LC-50 pada penelitian ini menggunakan metode probit. Nilai tersebut yang digunakan sebagai acuan dalam melakukan uji toksisitas limbah cair industri batik yang dilanjutkan dengan uji one way Anova.

\section{HASIL DAN PEMBAHASAN}

HASIL

\section{Faktor Fisika Kimia Limbah Cair Industri Batik}

Karakteristik buangan industri batik meliputi dua hal, yaitu karakteristik fisika dan kimia yang meliputi padatan TSS, $\mathrm{pH}$, kandungan kromium (Cr), dan COD. Hasil pemeriksaan kualitas limbah cair batik dan kadar maksimum limbah cair tekstil bagi kegiatan industri golongan I (industri ringan) berdasarkan Keputusan Menteri Negara Lingkungan Hidup Nomor : Kep51/MENLH/10/1995 disajikan dalam Tabel 1
Tabel 1. Hasil Pemeriksaan Kualitas Limbah Cair Industri Batik

\begin{tabular}{ccc}
\hline Parameter & $\begin{array}{c}\text { Hasil } \\
\text { Pemeriksaan } \\
\text { Limbah Cair }\end{array}$ & $\begin{array}{c}\text { Kadar } \\
\text { Maksimum } \\
\text { Limbah Cair } \\
\text { Tekstil }\end{array}$ \\
\hline COD & $4951,75 \mathrm{mg} / \mathrm{L}$ & 150 \\
Cr & 7,0 & 1,0 \\
TSS & 448 & 50 \\
pH & 6,9 & $6,0-9,0$ \\
\hline
\end{tabular}

Faktor fisika dan kimia limbah cair industri batik yang harus diperhatikan sebagai pencemar lingkungan diantaranya COD, TSS, dan kandungan logam berat yang terkandung di dalamnya.Hasil pemeriksaan kadar COD yang terkandung di dalam limbah cair industri batik sebesar 4951,75 mg/L. Hal tersebut melebihi kadar maksimum yang diperbolehkan berada di lingkungan yakni sebesar $150 \mathrm{mg} / \mathrm{L}$. Analisis kadar TSS limbah cair batik menunjukkan hasil 448 mg/L. Sedangkan kadar maksimum yang diperbolehkan dibuang di lingkungan yaitu 50 $\mathrm{mg} / \mathrm{L}$, artinya kadar TSS limbah cair batik melebihi batas maksimum limbah cair tekstil yang ditentukan. Hasil analisis kadar kromium (Cr) sebesar 7,0 mg/L. Kadar tersebut nilainya lebih tinggi jika dibandingkan dengan kadar maksimum kromium (Cr) dalam lingkungan yaitu $1,0 \mathrm{mg} / \mathrm{L}$. Sedangkan hasil pengukuran pH sebesar 6,9 menunjukkan $\mathrm{pH}$ limbah cair batik masih berada pada kisaran $\mathrm{pH}$ normal.

\section{Uji $L C-50$}

Uji LC-50 dilakukan untuk menentukan konsentrasi yang akan digunakan pada uji toksisitas limbah cair industri batik terhadap sisik ikan nila gift. Pengenceran yang digunakan dalam uji LC-50 yaitu $0 \%$; $0,5 \%$; $0,625 \% ; 0,75 \% ; 0,875 \%$ dan $1 \%$. Hasil pengamatan rerata mortalitas benih ikan nila gift dalamuji LC-50 96 jam pada konsentrasi $0 \%$ tidak menunjukkan mortalitas. Sedangkan pada konsentrasi $0,5 \%$ sebesar 0,4 ; konsentrasi $0,625 \%$ sebesar 2,6 ; konsentrasi $0,75 \%$ sebesar 5,6; dan pada konsentrasi 0,875\% sebesar 8,2. Konsentrasi tertinggi pada uji LC-50 yaitu $1 \%$ menunjukkan rerata mortalitas benih ikan nila gift sebesar 9,6. Berdasarkan hasil yang 
diperoleh menunjukkan bahwa mortalitas 50\% benih ikan nila gift pada limbah cair industri batik selama 96 jam terdapat pada interval konsentrasi $0,625-0,75 \%$.

Nilai LC-50 96 jam limbah cair industri batik yang diperoleh dengan menggunakan analisis Probit, yaitu sebesar $0,73 \%$. Nilai LC50 yang diperoleh menunjukkan toksisitas limbah cair industri batik terhadap ikan nila gift. Hal ini menunjukkan bahwa semakin besar harga LC-50 berarti toksisitasnya semakin kecil, dan sebaliknya semakin kecil harga LC50 maka semakin besar toksisitasnya. Mengacu pada kriteria tingkatan racun menurut Rossiana (2006), maka tingkat toksisitas limbah cair industri batik dapat dikategorikan ke dalam kriteria toksik tinggi.

\section{Uji Toksisitas Limbah Cair Batik}

Uji toksisitas limbah cair industri batik dilakukan untuk menentukan konsentrasi toksikan yang dapat menyebabkan mortalitas terhadap benih ikan nila gift (Oreochromis niloticus)dalam waktu yang relatif singkat.Konsentrasi yang digunakan dalam uji toksisitas limbah cair batik mengacu pada uji LC-50 96 jam, sehingga ditentukan deretan konsentrasi yang digunakan pada uji toksisitas limbah cair batik yaitu $0 \% ; 0,37 \% ; 0,46 \%$; $0,55 \% ; 0,64 \%$; dan $0,73 \%$.

Hasil pengamatan mortalitas benih ikan nila gift selama uji toksisitas limbah cair industri batik disajikan pada Gambar 1.

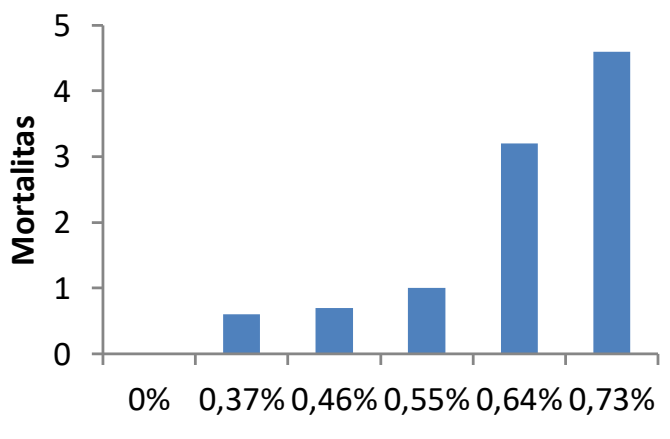

Konsentrasi limbah cair batik

Gambar 1. Mortalitas Benih Ikan Nila Gift (Oreochromis niloticus) selama Uji Toksisitas Limbah Cair Industri Batik
Gambar 1. menunjukkan rerata mortalitas benih ikan nila gift pada konsentrasi $0 \%$ menunjukkan 0 ; pada konsentrasi $0,37 \%$ sebesar 0,6 ; konsentrasi $0,46 \%$ sebesar 0,7 ; konsentrasi $0,55 \%$ sebesar 1 ; konsentrasi $0,64 \%$ sebesar 3,2; dan konsentrasi tertinggi pada uji toksisitas limbah cair batik yaitu $0,73 \%$ menunjukkan rerata mortalitas sebesar 4,6.

Untuk mengetahui signifikansi pengaruh limbah cair industri batik terhadap mortalitas benih ikan nila gift dilakukan uji one way Anova dengan tingkat kepercayaan 95\% $(\alpha=0,05)$.Berdasarkan hasil uji pengaruh limbah cair industri batik terhadap mortalitas benih ikan nila gift selama 96 jam diperoleh hasil yang signifikan. Selanjutnya dilakukan uji LSD untuk mengetahui pengaruh paparan limbah cair industri batik terhadap mortalitas benih ikan nila gift yang menunjukkan hasil bahwa antara konsentrasi $0 \% ; 0,37 \% ; 0,46 \%$; dan $0,55 \%$ memberikan pengaruh yang tidak berbeda nyata, tetapi berbeda nyata pada konsentrasi $0,64 \%$ dan $0,73 \%$. Hubungan mortalitas benih ikan nila gift dengan konsentrasi limbah cair batik selama 96 jam dalam uji toksisitas akut adalah berhubungan linier secara positif yang ditunjukkan pada Gambar 2.

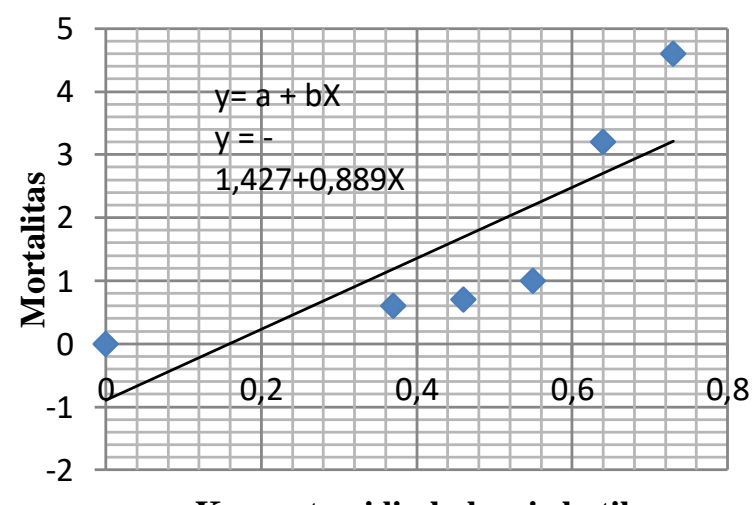

Konsentrasi limbah cair batik

Gambar 2. Hubungan Mortalitas Benih Ikan Nila Gift (Oreochromis niloticus) dengan Konsentrasi Limbah Cair Industri Batik

Hasil yang diperoleh menunjukkan hubungan mortalitas benih ikan nila gift dengan konsentrasi limbah cair industri batik 
Jurnal SainHealth Vol. 1 No. 2 Edisi September 2017

(C) Fakultas Ilmu Kesehatan Universitas Maarif Hasyim Latif Sidoarjo

p-ISSN : 2548-8333

e-ISSN : 2549-2586

didapatkan persamaan regresi, yaitu $\mathrm{y}=-1,427$ $+0,889 \mathrm{X}$ dengan $a=-1,427$ dan $\mathrm{b}=0,889$. Sedangkan koefisien regresi konsentrasi limbah (X) sebesar 0,889 bernilai positif, artinya terjadi hubungan positif antara konsentrasi limbah cair batik dengan mortalitas benih ikan nila gift, semakin tinggi konsentrasi limbah maka semakin besar mortalitas pada benih ikan nila gift.

\section{Morfologi Sisik Benih Ikan Nila Gift (Oreochromis niloticus)}

Hasil pengamatan morfologi sisik benih ikan nila gift (Oreochromis niloticus) dari berbagai konsentrasi limbah cair batik selama 96 jam menggunakan mikroskop dengan perbesaran 10x40 seperti ditunjukkan pada Gambar 3.
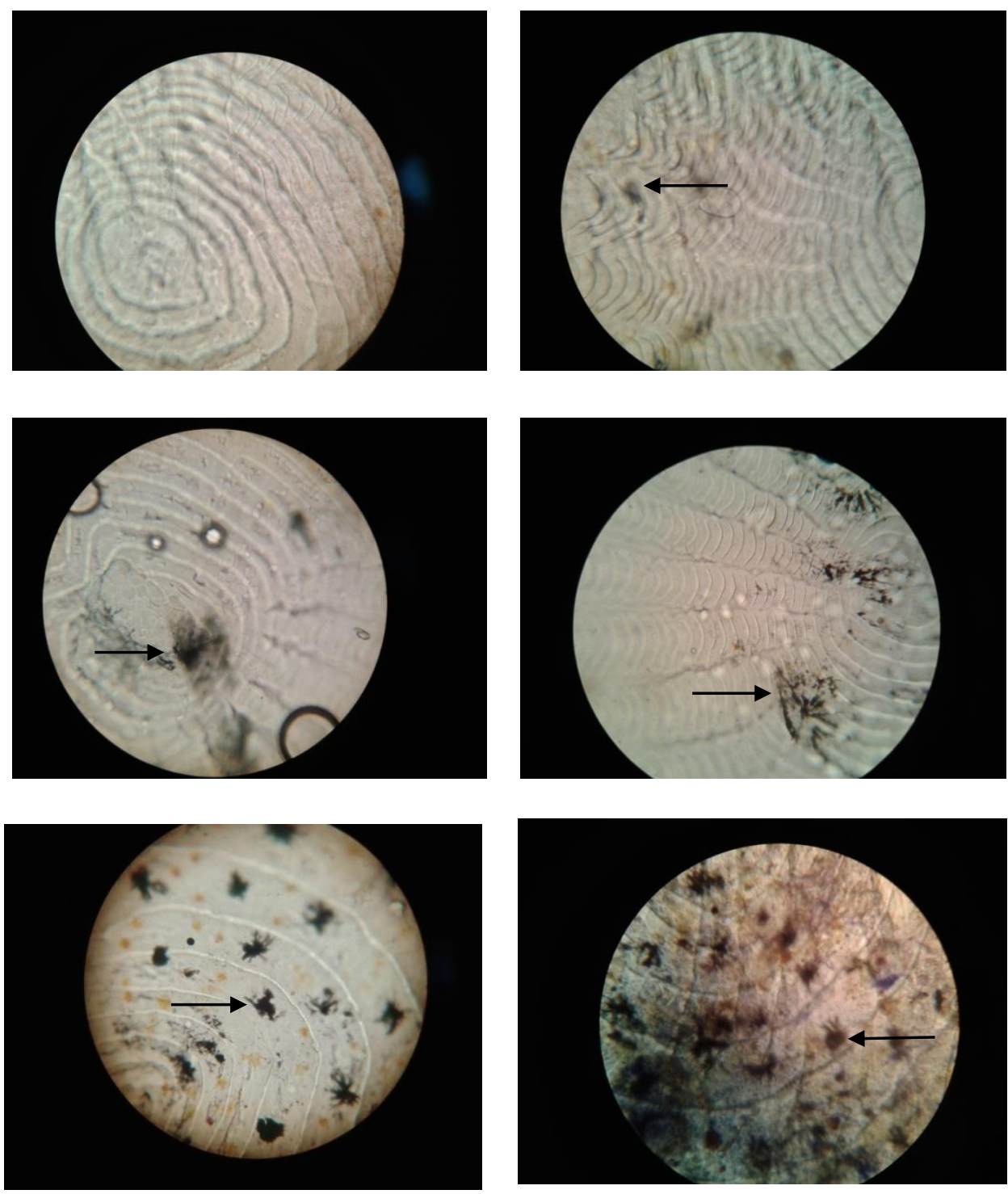

Gambar 3. Morfologi Sisik Benih Ikan Nila Gift (Oreochromis niloticus) dengan Perbesaran Mikroskop 10x40. (a) konsentrasi 0\%; (b) konsentrasi 0,37\%; (c) konsentrasi 0,46\%; (d) konsentrasi 0,55\%; (e) konsentrasi 0, 64\%; (f) konsentrasi 0,73\%.

Hasil pengamatan menunjukkan sisik benih ikan nila gift (Oreochromis niloticus) yang terpapar langsung oleh limbah cair industri batik terjadi penempelan zat asing yang 
ditunjukkan dengan tanda panah. Penempelan zat pada sisik benih ikan nila gift berbeda pada tiap perlakuan yang diberikan. Perlakuan pertama $(0 \%)$ morfologi sisik terlihat bersih dan tidak terjadi penempelan zat. Perlakuan kedua dengan konsentrasi $0,37 \%$ terjadi penempelan zat yang tidak terlihat jelas dan sangat sedikit. Perlakuan ketiga konsentrasi $0,46 \%$ tanda panah menunjukkan penempelan zat asing yang cukup terlihat dibanding konsentrasi sebelumnya. Namun hasil yang ditunjukkan antara perlakuan ketiga $(0,46 \%)$ dan perlakuan keempat $(0,55 \%)$ menunjukkan hasil yang hampir sama tidak berbeda secara nyata. Perlakuan kelima dengan konsentrasi $0,64 \%$ memperlihatkan hasil penempelan zat asing yang cukup banyak. Sedangkan pada perlakuan keenam konsentrasi tertinggi yaitu $0,73 \%$ menunjukkan hasil penempelan zat asing yang memenuhi penampang sisik benih ikan nila gift. Kerusakan sisik hanya terlihat dari warna sisik ikan nila gift. Tidak terlihat kerusakan bentuk maupun ukuran pada sisik benih ikan nila gift (Oreochromis niloticus) pada semua perlakuan. Ukuran sisik benih ikan nila gift (Oreochromis niloticus), yaitu $0,5 \mathrm{~mm}$, bentuk sisik pada tiap perlakuan tidak ada yang mengalami kelainan, dan bagian sisik pada setiap perlakuan masih jelas terlihat.

\section{PEMBAHASAN}

Limbah cair industri batik merupakan salah satu sumber pencemaran terhadap lingkungan perairan. Karakteristik air buangan dari limbah yang dihasilkan selama pewarnaan batik berbeda karena berasal dari proses yang berbeda. Chemical Oxygen Demand (COD) menunjukkan jumlah oksigen dalam proses oksidasi secara kimia (Mahida, 1984). Menurut Clare (2002) dan Sulaksono (2014), kandungan COD yang tinggi dalam limbah menjadi penyebab kematian benih ikan nila gift (Oreochromis niloticus) karena dapat menurunkan kandungan oksigen terlarut dalam media, akibatnya oksigen tidak dapat terpenuhi sehingga menyebabkan kematian.

$$
\text { Total Suspended Solids }
$$
menunjukkan kandungan bahan padat organik dan anorganik yang tersuspensi di dalam air, padatan organik ini menyebabkan warna air menjadi keruh (Wardhana, 2001). Kadar TSS pada sampel limbah cair batik dalam penelitian lebih tinggi dibandingkan kadar maksimum dalam perairan, sehingga dapat mempengaruhi kandungan oksigen terlarut dalam air. Semakin tinggi kadar TSS, maka kadar oksigen terlarut semakin rendah, sehingga mengakibatkan air limbah menjadi toksik untuk biota perairan apabila kadar oksigen terlarut dalam air tersebut rendah (Odum, 1994).

Sampel limbah cair industri batik yang dianalisis menunjukkanterdapat kandungan kromium $(\mathrm{Cr})$ yang melebihi kadar maksimum yaitu sebesar 7,0 mg/L. Jika nilai tersebut dikonversikan, maka kadar kromium yang terdapat pada konsentrasi limbah 0,73\% sebagai hasil LC-50 96 jam adalah sebesar $10,429 \%$. Hal ini sejalan dengan penelitian yang dilakukan Kuykendall, et al. (2005) dimana nilai LC-50 96 jam kromium terhadap invertebrata akuatik berada pada rentang $0,66-$ 64\%.Kandungan $\mathrm{Cr}$ berasal dari zat warna yang digunakan pada proses pewarnaan. Kandungan kromium yang tinggi pada limbah cair batik dapat menyebabkan kerusakan jaringan pada ikan. Senyawa kimia ini dapat masuk dengan 3 cara yakni melalui insang, mulut, dan kulit (Hadiyati, 2004). Sedangkan hasil pengukuran $\mathrm{pH}$ sebesar 6,9 menunjukkan $\mathrm{pH}$ limbah cair batik masih berada pada kisaran normal.

Hubungan antara tingkat toksisitas limbah cair batik dengan mortalitas benih ikan nila gift (Oreochromis niloticus) adalah berbanding lurus. Semakin tinggi tingkat toksikan yang diberikan, maka mortalitasbenih ikan nila gift juga semakin besar. Hal ini disebabkan oleh tingkat toksikan yang semakin tinggi maka akan terjadi akumulasi yang tinggi pula sehingga mortalitas benih ikan nila gift akan semakin besar. Mustofa (2010) menyatakan bahwa limbah batik dalam konsentrasi yang tinggi menyebabkan frekuensi pernafasan ikan dan konsumsi oksigen meningkat 213 kali kemudian diikuti dengan 
penurunan ritme pernafasan, kehilangan keseimbangan, dan akhirnya ikan anak mengalami kematian dengan mulut dan operculum terbuka lebar yang menandakan terjadi sufofikasi. Penyebab kematian ikan adalah karena kerusakan ephithelium insang oleh limbah cair batik yang mengandung logam kromium dan akibat penyumbatan saluran branchiolanya sehingga pertukaran gas terganggu dan ikan mati lemas.

Hasil uji LC-50 menunjukkan nilai $0,73 \%$ yang artinya limbah cair industri batik termasuk kategori toksik tinggi. Kondisi ini disebabkan kerena pada industri ini tidak dilakukan IPAL sehingga kadar toksikan berupa logam toksik kromium yang digunakan dalam industri batik masuk ke dalam tubuh makhluk hidup bersama makanan atau minuman (Mujosemedi, 1985). Penyebab tingginya tingkat kematian pada benih ikan nila gift (Oreochromis niloticus) dalam limbah cair batik yaitu terdapat kandungan zat berbahaya yang terdapat pada limbah cair batik seperti kromium yang mencapai angka 7,0 mg/L. Supraptini (2002) menyatakan bahwa kandungan tertinggi dalam limbah cair batik adalah logam berat berupa kromium.

Logam berat krom merupakan salah satu zat pencemar yang sangat berbahaya. Bagi kesehatan manusia logam berat krom dapat menyebabkan kanker, sedangkan diketahui logam berat ini pada ikan dapat menyebabkan penebalan pada dinding epitel insang ikan sehingga ikan akan sulit untuk mengambil oksigen terlarut dalam air.Sedangkan penelitian lainnya menyebutkan bahwa kromium dapat ikut beredar di dalam darah dan menyebabkan gangguan sistem transportasi pada tubuh hewan, seperti yang telah diketahui bahwa benih ikan nila gift (Oreochromis niloticus) memiliki hemoglobin yang berfungsi untuk mengikat oksigen (Clare, 2002). Adanya limbah cair industri batik dapat menurunkan kadar oksigen dalam air, sehingga menyebabkan benih ikan nila gift kekurangan oksigen yang dapat mengganggu proses fisiologis dalam tubuhnya, dan apabila berlanjut terus menerus dapat menyebabkan kematian terhadap benih ikan tersebut.

Hemoglobin merupakan komponen yang paling penting dalam proses pengikatan oksigen di dalam darah, karenasalah satu sifat dari hemoglobin adalah dapat berikatan dengan ion logam, sehingga kromium akan terurai dan berikatan dengan sisi aktif hemoglobin. Adanya ikatan hemoglobin dari kromium tersebut akan mengakibatkan penghambatan proses pengikatan oksigen. Hal tersebut dapat mengakibatkan proses respirasi di dalam tubuh benih ikan nila gift terhambat, yang mengakibatkan penurunan proses penghasilan energi. Apabila keadaan tersebut berlangsung terus menerus, maka akan mengakibatkan defisiensi energi yang berujung pada kematian benih ikan nila gift. Amelita (2002) menyebutkan dalam penelitiannya bahwa kandungan kromium dalam media dapat mengakibatkan keracunan dan kematian pada benih ikan nila gift (Oreochromis niloticus) dengan hasil dari uji toksisitas penelitian tersebut besarnya kromium yang menyebabkan kematian 50\% pada waktu 24 jam dan 48 jam adalah pada rentang 15-68 ppm.

Hasil penelitian yang telah dilakukan menunjukkan hubungan mortalitas benih ikan nila gift (Oreochromis niloticus) berbanding lurus dengan konsentrasi limbah cair batik. Sesuai dalam penelitian yang dilakukan oleh Jumedi (2003) yang menyebutkan bahwa hubungan konsentrasi limbah cair industri batik terhadap ikan gabus dan kerapu. Hubungan antara konsentrasi limbah cair batik terhadap mortalitas ikan nila nila gitf disebabkan oleh daya toksik limbah tersebut pada tingkat konsentrasi tertentu yang dapat mematikan organisme uji.

Logam berat dapat masuk ke dalam tubuh benih ikan nila gift melalui berbagai cara diantaranya difusi permukaan kulit, konsumsi oksigen yang terkontaminasi, ataupun air dari medium yang diberi perlakuan. Logam berat tersebut kemudian akan terakumulasi dalam 
tubuh benih ikan nila gift. Menurut Moore dan Ramamoorthy (1984) serta Helawell (1986), ada beberapa faktor yang mempengaruhi tingkat toksisitas suatu bahan, yaitu berupa keadaan kimia fisik lingkungan ( $\mathrm{DO}, \mathrm{pH}$, suhu) dan kandungan bahan tersebut. Selain itu, lamanya uji serta spesies benih ikan nila gift yang digunakan juga dapat mempengaruhi tingkat toksisitas suatu bahan (Dhahiyat, 1999). Kematian benih ikan nila gift (Oreochromis niloticus) dapat disebabkan karena masuknya limbah cair industri batik ke dalam tubuh.Pennak (1996) menyebutkan bahwa benih Oreochromis niloticus menyerap bahanbahan organik dan anorganik oleh permukaan tubuhnya.

Sisik yang dimiliki benih ikan nila gift (Oreochromis niloticus) berfungsi sebagai protektor untuk mencegah bahan toksik masuk kedalam tubuhnya. Hampir semua benih ikan nila gift pada konsentrasi 0,37\%-0,73\% dalam penelitian menunjukkan adanya penempelan zat asing pada sisiknya yang berasal dari limbah cair batik. Sisik sebagai salah satu organ terluar dari ikan yang terpapar oleh zat asing maka pengaruhnya dapat diamati secara langsung. Besar kecilnya penempelan zat berbanding lurus dengan besar kecilnya konsentrasi toksikan yang diberikan. Semakin besar konsentrasi toksikan maka penempelan zat asing juga semakin besar. Hal ini terjadi karena semakin besar konsentrasi toksikan maka akan terjadi akumulasi zat dari limbah cair industri batik. Namun pada sisik ikan nila gift tidak terjadi kerusakan bentuk sisik. Pada masingmasing perlakuan tidak terjadi perubahan bentuk dari perlakuan kontrol. Bagian dari masing-masing sisik masih jelas terlihat dan tidak ada indikasi yang mengarah kepada kerusakan bentuk dan ukuran.

\section{DAFTAR PUSTAKA}

Amelita. 2002. Studi Tentang Pengaruh Logam Kromium (Cr) Dalam Limbah Cair Industri Penyamakan Kulit Pt. Budi Makmur Yogyakarta Terhadap
Kelangsungan Hidup Ikan Mas (Cyprinus Carpio).

Boyd. 1990. Water Quality in Fish Ponds for Aquaculture. Alabama agricultural experiment stasiun. Auburn Universty of Alabama.

Clare. 2002. Daphnia an Aquarist's Guide. http//www.caudata.org /daphnia. Diakses Juni 2017.

Dhahiyat dan Djuangsih. 1997. Uji Hayati (Bioassay); LC 50 (Acute Toxicity Tests) Menggunakan Daphnia dan Ikan. PPSDAL LP UNPAD. Bandung.

Hadiyati. 2004. Uji Toksisitas Limbah Cair Penyamakan Kulit Terhadap Ikan Lele.Jurusan Biologi FMIPA Unpad. Jatinangor.

Hellawell. 1986. Biological Indicators of Freshwater Pollution and Environmental Management. Pollution Monitoring Series. Elsevier Applied Science Publishers. London.

Jumedi. 2003. Uji Toksisitas Akut Limbah Cair Batik terhadap Biota Uji Ikan Gabus dan Kerapu. Jurusan Teknik Lingkungan. Institus Teknologi Sepuluh November. Surabaya.

Kuykendall, J.R., K.L. Miller, K.N. Mellinger, A.V. Chain. 2005. Waterborne and Dietary Hexavalen Chromium Exposure Causes DNA protein Crosslink (DPX) Formation in Erythrosites of Largemouth Bass (Micropterus salmoides). Aquatic Toxicology. Ohio.

Mahida.1984. Pencemaran air dan Pemanfaatan Limbah Industri.CV. Radjawali: Jakarta.

Mangkoedihardjo. 2005. Remediation Technologies Selection for Oil-Polluted Marine Ecosystem. Jurusan Teknik Lingkungan, Fakultas Teknik Sipil dan Perencanaan. Institut Teknologi Sepuluh Nopember. Surabaya.

Martinezdan Marina. 2007. Histopathology Of Gills, Kidney and Liver of A Neotropical Fish Caged In An Urban Stream. Neotropical Ichthyology.

Masfufah, Intan, dan Rina. 2007. Uji Toksisitas Limbah Cair Batik terhadap Reproduksi dan Pertumbuhan Daphnia magna. http://pustaka.unpad.ac.id/wpcontent/uploads/2009/ 04/uji_toksisitas_limbah_cair_penyama kan_kulit.pdf. Diakses 2017. 
Moore dan Ramamoorthy. 1984. Heavy Metals in Natural Water Applied. Monitoring and Impact Assessment. SpringerVerlag. New York-Berlin-HeidelbergTokyo.

Mujosemedi.1985. Beberapa Aspek Pencemaran Limbah Pabrik PT. Batik Keris di Perairan Sungai Premulung Surakarta. Skripsi. Fakultas Biologi UGM. Yogyakarta.

Mustofa. 2010. Kerusakan Jaringan Ikan Nila Akibat Kromium. Program Studi Manajemen Sumberdaya Perairan Jurusan Perikanan Fakultas Perikanan Dan Ilmu Kelautan Universitas Diponegoro.

Odum. 1994. Dasar- Dasar Ekologi. EdisiKetiga. TerjemahanolehKoesbiono, D.G. Bengon, M. Eidmen dan S. Sukarjo. Gramedia. Jakarta.

Pennak. 1996. Fresh-water invertebrates of the United States. The Ronald Press Company.

Radiopoetra, 1996. Kualitas Air Untuk Ikan Hias Air Tawar. Proyek Buku Terpadu. Jakarta.

Rossiana, N. 2006. Uji Toksisitas Limbah Cair Tahu Sumedang terhadap Reproduksi
Daphnia carinata KING. Jurusan Biologi Fakultas Matematika dan Ilmu Pengetahuan Alam Universitas Padjadjaran. Bandung.

Soegianto, Adiani, dan Winarni. 2004. Pengaruh Pemberian Kadmium terhadap Tingkat Kelangsungan Hldup Dan Kerusakan Struktur Insang Dan Hepatopankreas Pada Udang Regang [Macrobrachiurn sintangense (de Man)]. Jurusan Biologi. Fakultas Matematika Dan ilmu Pengetahuan Alam. Universitas Airlangga. Surabaya. Sulaksono. 2014. Kajian Beban Pencemaran Limbah Cair Industri Kecil Menengah (Ikm) Batik Klaster Trusmi Kabupaten Cirebon. www.academia.edu. Diakses Juli 2017.

Supraptini. 2002. Pengaruh Limbah Industri Terhadap Lingkungan di Indonesia. Jurnal Linkungan. Vol 17/No. 2. Jurusan Biologi FMIPA Unnes. Semarang.

Wardhana. W.A. 2001. Dampak Pencemaran Lingkungan. Andi Yogyakarta. Yogyakarta. 